\title{
Do Governance, Foreign Direct Investment and Human Capital Matter to Bolster Trade Liberalization? Fresh Insight from Developing Countries
}

\author{
Muhammad Umar ${ }^{a}$, Imran Sharif Chaudhry ${ }^{b}$, Muhammad Faheem ${ }^{c}$, Fatima Farooq ${ }^{d}$ \\ ${ }^{a}$ MPhil Scholar, School of Economics Bahauddin Zakariya University, Multan, Pakistan \\ Email: mailumarramzan@gmail.com \\ ${ }^{\mathrm{b}}$ Dean of Social Sciences and Director, School of Economics Bahauddin Zakariya University, Multan, \\ Pakistan \\ Email: imran@bzu.edu.pk \\ ${ }^{c}$ Assistant Professor, School of Economics Bahauddin Zakariya University, Multan, Pakistan \\ Email: faheem@bzu.edu.pk \\ d Associate Professor, School of Economics, Bahauddin Zakariya University, Multan, Pakistan \\ Email: fatimafarooq@bzu.edu.pk
}

\begin{tabular}{l}
\hline ARTICLE DETAILS \\
\hline History: \\
Accepted 22 July 2021 \\
Available Online September 2021
\end{tabular}

Keywords:

Trade Liberalization, Human

Capital, Governance, Developing

Countries, Fixed Effect

JEL Classification:

P33, J24, G39,O57

DOI: $10.47067 /$ reads.v7i3.369

\begin{abstract}
This study aims to explore the impact of governance, foreign direct investment and human capital on trade liberalization in developing countries (lower income, middle income and upper middle income). The study employed fixed effect for the period of 2000 to 2019. Results show governance, foreign direct investment and human capital are highly significant with trade liberalization in the case of lower-income countries. In the case of middle-income countries, empirical findings demonstrate governance and foreign direct investment are highly significant with a negative sign, while human capital has positive on trade liberalization. In the case of upper-middle-income countries, results show human capital and foreign direct investment affect positively, while governance has a negative effect on trade liberalization. On the behalf of results it is suggested that in the countries where human capital is high, most of the inflows of foreign direct investment happen. It means that the government can develop human resources to attract more foreign direct investments. The governments of developing countries should also concentrate on education, including training facilities and other quality educational facilities for human skill development.
\end{abstract}

(C) 2021 The authors. Published by SPCRD Global Publishing. This is an open access article under the Creative Commons Attribution-

NonCommercial 4.0

Corresponding author's email address: fatimafarooq@bzu.edu.pk

\section{Introduction}

The role of governance is a necessary component of development effectiveness. The government, however, plays a crucial role in the distribution of economic resources (Azam, 2021; Xu et al., 2021). 


\section{Review of Economics and Development Studies, Vol. 7 (3) 2021, 325 - 341}

Also, its essential for the social association, political order, rules and regulations, trade policy, and economic growth. The private sector has problems supplying such goods, such as defence, schooling, and health care as the government would obtain them (Fazekas \& Czibik, 2021; Khan et al. 2019; Lahouij 2016; Akujuru et al. 2015). Governance is a prominent force in the growth process, but what does progress in administration concentrate on in developing countries? The advice given to emerging countries has focused on building governance skills referred to as "good governance," which focuses on creating land, eliminating corruption, the rule of law, and the refinement of transparency by the government (Khosroabadi 2016). However, historical evidence does not indicate that developing nations can establish these capabilities at a level that will dramatically affect their long-term progress. These are entirely essential requirements for governance. Instead, the evidence shows that stable developing countries have more accurate administration that allows prosperity and stability to be sustained. These skills were country-specific, considering the substantial difference in initial structural and political circumstances around countries and the economic challenges to be tackled. It is a considerable understanding that promoting growth in developing countries is a challenge for identifying the right economic policies and preserving adequate management capacities that are chronically lacking in developing countries. Therefore, government weaknesses in poorly performing areas around the world have gained a great deal of consideration. However, the specific governance skills needed to stimulate and manage growth in countries at differing stages of development and face diverse development challenges are considerably less accepted (Akujuru et al. 2015).

In developing countries, foreign direct investment (FDI) is a crucial way to finance it (Li et al., 2021). FDI takes into account cash or non-cash inflows and provides advantages for the host countries. Foreign direct investments have beneficial impacts on the economy through moving technical knowledge and capital. Due to some complications, many countries avoid foreign direct investment. That is the basis of international borrowing and the cause of non-debt inflows to achieve the targets. By use of resources generates funds for developing countries (Zakarias 2016; Shuaib et al. 2015). Foreign direct investment is not the only source of private financing and a source of technology changes, management expertise, and information and employment. Foreign direct investment in developing countries has a significant outflow and macro and micro-level instability. An increase in exports and capital stimulates foreign direct investment. Foreign direct investment is overcoming the disparity between domestic spending and domestic savings. Foreign direct investment provides different forms of investment for global and domestic investors. Foreign direct investment is a base of a transformation of technological skills, managing capital, and access to markets for a sustainable economy (Dada \& Abanikanda, 2021; Osei \& Kim 2020; Samantha et al. 2017; Maliwa \& Nyambe 2015; Emmanuel 2014; Zeb et al. 2013; Agrawal et al. 2011).

Empirical studies have generally recognized the value of human capital as an engine for economic prosperity and growth like other indicators of economic growth (Maitra \& Chakraborty, 2021; Matousek \& Tzeremes, 2021; Chaudhry et al., 2021; Anwar et al., 2016). No nation may archive its sustainable growth goals without investing in human resources. Human beings are considered a country's most valuable commodity. Human capital has played a crucial role in improving people's talents, skills, and capacities to contribute to their growth (Muringani,2021; Özdoğan, 2021; Ahmad et al., 2021). The two key determinants of human capital are health and education. State investment in the health and education sectors should be expanded. This investment helps growing numbers of people to benefit from simple living needs(Fang \& Chang 2016; Awan et al. 2015; Azam \& Ahmad 2014; Chani et al. 2012)

The remaining sections of the paper are as follows: section 2 is about previous literature. Section 3 
Review of Economics and Development Studies, Vol. 7 (3) 2021, 325 - 341

demonstrates the data and methodology. Section 4 explains the empirical results and the last section provides the conclusion and recommendations.

\section{Literature Review}

Abdelbary \& Benhin (2019) contributed to the ongoing deliberation on the factors that enhance economic development in the air conditions in association with other states in the world with an emphasis on the often-ignored role of supremacy in growing. The study found clear evidence that human capital and investment have had a significant positive impact on growth, but that regulatory efficiency has had a significant negative impact. The most striking finding from the standard model is that growth in the whole sample is important and surely defined by the coefficient of governance, whereas it is negative in the sample of air conditions.

Fraj et al. (2018) examined the governance and economic development relationship with an emphasis on exchange rate governance. Results showed that good governance promotes flexible exchange rate regime selection, and that stability in exchange rates require better governance to promote economic growth in developing countries. Efficient management speeds up economic growth in industrialized countries if the exchange rate system is not too volatile, while stability in exchange rates improves economic output if regulation is not a good standard. Estimates have also demonstrated that the existence of the exchange-rate system plays a key role in the decision to increase the standard of governance. The optimum exchange rate system is calculated by the standard of governance. On the traditional side, the relationship between the general governance index and the grade of transaction versatility is statistically important, reflecting the significance of theoretic and methodological foundations brought up in this study. Khosroabadi (2016) analyzed the impacts of quality control metrics on income allocation for Turkey, Pakistan, and Iran in the surrounding economies. The findings suggest that, as a result of the ups and downs of the Governance Index in Iran, the overall governance quality index was weaker and the governance quality index in Turkey was much better compared to Iran and Pakistan and that, for each of the three countries, a major negative link existed between them. The findings indicated a negative impact on the decrease of inequalities from the standard index of governance that may successively show the increase of the impact of these metrics on income sharing.

Akujuru et al. (2015) investigated good governance, city government, and sustainable development in Nigeria. The survey identified crucial issues in Nigeria, which include a shortage of employment, a lack of resources to implement local government services and corruption, lack of effective governance preparation, lack of transparency and accountability, non-government cooperation, and the absence of a government to ensure good governance, and economic empowerment of the people. It was obvious and established from the report that good governance encourages empowerment and economic growth in the regional administrations of Emohua. It was also proposed that local councils concentrate on projects that will empower local people instead of mutual cash transfers and controls. Iqbal et al. (2015) analyzed the governance problems and they're on income inequality in Pakistan to explore the association between governance and inequality. There has been a major negative association between government and income inequality. Pakistan has faced poor democratic governance, due to an unstable regional government, considered a critical state.

Osei \& Kim (2020) explored the effect of foreign direct investment on economic growth is affected by an increase in financial development. They found substantial evidence that foreign direct investment generally fosters growth, but when the ratio of private sector credit to gross domestic product reaches 95.6 percent, the growth impact of foreign direct investment becomes marginal. This result is robust to various econometric approaches, diverse subsamples and analysis of interactions, and 
Review of Economics and Development Studies, Vol. 7 (3) 2021, 325 - 341

distinct measures of financial growth. Nantwi \& Erickson (2019) analyzed the effect of foreign investment on South American countries' economic development. In a grid of ten South American countries, the Pedroni Cointegration Test ensures a long-term association of foreign direct investment and economic growth. This research long-run projection identified major positive effects of foreign direct investment on regional economic development. Short-run multimodal causality between foreign direct investment and development was found in the vector error correction model findings. Negative and important is the error term. This suggests the nature of the variables' long-run balanced relationship.

Sokang (2018) investigated the effect of foreign direct investment on Cambodia's economic development. The research findings indicate that foreign direct investment is having a favorable influence on Cambodia's economic growth. This direct correlation may benefit from an appropriate foreign direct investment fund being financed in the economy of Cambodia, which has been able to exert sufficient influence to turn it positive or to boost development. Samantha et al (2017) explored foreign direct investment effects on Sri Lanka economic development. The findings of this study confirm the long-term relationship between the variables. Foreign direct investment is favorably associated with short- and long-term economic growth but is not a significant factor in Sri Lanka's economic development.

Siddique et al. (2017) examined the nexus of foreign direct investment to Pakistan's economic development. The results show the co-integration that persists between economic development, foreign direct investment, trade, physical capital, and human resources. The short-run results for fixed capital, foreign direct investment, and human capital are important and optimistic. In the short term, variable labor and trade have a negative effect on production. Real capital, foreign direct investment, intellectual resources, and trade have a positive impact on economic development in the long term. The findings also demonstrate the causality of one-way economic development to foreign direct investment, physical capital, labor, and trade. The results also reflect the one-way causality of labor and physical capital from human capital to the workforce. There are bidirectional causes and effects between foreign direct investment and physical capital, and between physical and human capital. There is no relationship between trade and any other factor about causality. It means the government should develop human skills to draw more foreign direct investment. Zekarias (2016) examined the effect of foreign direct investment in 14 eastern African economies on growth in production. Empirical studies show three fundamental realities, foreign direct investment has a positive impact on growth in production, a conditional balance has been observed at the 5 percent level, and local investment levels have never been decreased by foreign investment.

Maliwa \& Nyambe (2015) analyzed the foreign direct investment effect on economic growth in Zambia. Findings showed that foreign investment and economic development has no causal relationship, which means that during the time under review, the Zambian economy did not benefit from the inflow of foreign investment into the country. The absence of a positive impact of foreign investment on Zambia's economic growth may be triggered by the failure to meet some of the prerequisites of ensuring foreign investment is used effectively. Agrawal (2015) investigated the association between foreign direct investment and Economic Growth concerning BRICS nations. Econometric findings showed that, because massive foreign investment has impacted a huge increase in economic development in the selected countries, foreign direct investment has positively affected production growth. Also, foreign investment is closely interlinked with production growth, which means the association between two variables in a longer period. Causal approaches also shown that foreign direct investment and economic development have a long causal relationship. Jun (2015) 
Review of Economics and Development Studies, Vol. 7 (3) 2021, 325 - 341

analyzed the nexus of foreign capital investment and economic development of south Asian associations for regional cooperation countries. The integration of foreign direct investment and economic development was significant in two ways. A further study discussed strong two-way causality evidence from foreign direct investment to economic development. It was also stated that the large foreign investment was driven by foreign inflows to emerging economies up to the economic expansion and the resulting productivity increase. Findings indicate that CPI and free trade had relatively low economic development, while foreign direct investment, financial growth, human resources as well as government expenditures had a considerable positive impact.

Chowdhury et al. (2018) analyzed the importance of human capital on the growth of the economy. It has been postulated from the study that there is a solid, constructive relationship between the production of human resources and economic growth. In this model, life expectancy is considered to be the most significant predictor, as it has a major effect on Bangladesh's economic development. They recommended introducing workable strategies to bring about increased economic development. Health and public education spending should be used wisely and efficiently so that the nation can have reliable health care coverage and a high-quality school system.

Fang \& Chang (2016) said human capital plays a key role in the development of the economy. For the growth and production of factor input, the function of energy is extremely significant. The assets and human capital are in close association. In the economic growth of the world, Asia-Pacific countries play an important part. Asia-Pacific contributes 27.4 percent of global gross domestic product, with its share of energy demand increasing from 12 percent to 41 percent in 2014. For sixteen countries, the data from 1970 to 2011 is used. The findings of the analysis indicate that the two key contributors to economic growth are electricity and physical capital. The findings from the granger causality panel suggest that the granger induces energy for economic development. But relationships vary between countries. The role of energy in economic growth has been significant. The influence on regional economies is real to human resources.

Awan et al. (2015) said that many countries promoted their economy through_knowledge and technical revolution. It was realized that human resources were based on skills and knowledge. The role of human capital was vitally important for modern economic growth. Education was a very important factor for human development and help people to get a better jobs. The health sector was also very important for economic growth. The role of the education sector was very important for the living standard of the people because with the help of higher education and technical skills they can easily get better jobs. To achieve the objective of economic growth literacy rate must be improved in the country. The literacy rate is a key indicator of education for the long-run impact on the economy. The result of the study show that there is a positive and significant relationship is found between the variable. The result showed that one present increase in gross fixed capital increases economic growth by o.73percent.

Omotayo (2015) stated that the prosperity of the country is driven by human resources. Training is a central part of the production of human capital. The effect of human resources on economic growth is optimistic. Education investment is very poor in Nigeria relative to other African nations. In any country's growth, the role of education and health is very critical. The capability of individuals is strengthened by good health and education. Both elements are closely related. State funds the health and education system in several countries. Nigeria has a relatively high literacy rate. Many workers are unqualified and are unable in the production process to use modern technology. Education plays a significant role in growing people's talents and awareness. Data was used between 1980 and 2012. To 
Review of Economics and Development Studies, Vol. 7 (3) 2021, 325 - 341

assess the link between human resources and economic growth, the OLS methodology is used. The study shows that economic development and investment in human resources are substantially related to Nigeria.

Samar \& Waqas (2014) stated that a shortage of schooling, health care, and unemployment and skilled manpower was the primary cause of low economic development. In the development of human resources, the role of health and education was extremely significant. It contributed to growing people's efficiency, growth, and professional power in the region. Strong educational levels have also raised the country's revenue and expenses. Education and health expenditure in Pakistan was very poor compared with other countries worldwide. To meet sustainable development goals, spending should be expanded in both the education and health sector. This research used data from 1979 to 2010. The augmented dickey fuller root test unit was used as well as the co-integration and error correlation process. The study indicates that human capital is linked to economic development in the long run. The enrollment of college has a favorable economic growth relationship.

Gerhands \& Hans (2013) stated telecommunications, political, and cultural interactions were exponentially increasing because of globalization worldwide. The development of Europeanization would lead to the free exchange of goods, services, and staff in the European Union. The KOF index helps to calculate which country is in different ways linked to another country. The demands of individuals shifted, notably about jobs and schooling, due to the establishment of the European Union. The role of English in the world has expanded. English is quite useful for students since it is used in many countries around the world as an international language. In educational analysis, the role of human capital in educational fields is very important. This research uses data from 2000 to 2010 . The parents' investment in the education of their children aims to boost education. To evaluate the results, the logistic regression model is used.

Asghar et al. (2012) investigated the empirical study of Cointegration and Causality analysis on human capital and economic growth in Pakistan. They stated that the main goal of a nation is economic development and that it can be accomplished through human resources. Education, health care, and technological capabilities expenditure have played a key role in improving productivity and in leading to economic development. The role of human capital in economic development was very significant as healthy people were more efficient. Because of decreased social sector allocations, the government of Pakistan is not willing to benefit from human resources. Generally, there are limited conclusive results relating to empirical studies of the impacts of governance, human capital, and foreign direct investment on trade openness in developing countries due to differences in methods, measurement, sample size, area of the research, and data period.

\section{Data and Methodology}

The study covers the data from 2000-2019 for the developing countries (low-income, lowmiddle-income, and upper-middle-income countries). The data for this research is sourced from the two different sources; i.e; the data of trade, foreign direct investment, human capital, gross domestic product, broad money official exchange rate, personal remittances received and tax revenue is sourced from world development indicators. And world governance index (average of all six indicators) variable data is sourced from world governance indicators.

The simple linear model is as follows

$$
Y_{i t}=\alpha_{o}+\beta X_{i t}+\varepsilon_{i t}
$$


$\mathrm{x}$ and $\mathrm{y}$ are used as dependent and independent variables, and $(\mathrm{t})$ shows time. $\mathrm{t}=1,2,3, \ldots \mathrm{T}$.

There are two approaches of estimating for panel data random and fixed. This approach is helpful for the assessment of the panel data. The concept of fixed effect is used to test the influence of factors that differ over time. The constant for each set is unique in this model. The set approach is also known as LS Dummy Variables. For each group, this model allows for various constants. The fixed impact model equation becomes:

$$
\mathrm{Y}_{\mathrm{it}}=\beta_{\mathrm{o}}+\beta_{1} \mathrm{X}_{1 \mathrm{it}}+\beta_{2} \mathrm{X}_{2 \mathrm{it}}+\ldots \ldots . .+\beta_{\mathrm{k}} \mathrm{X}_{\mathrm{kit}}+\varepsilon_{\mathrm{it}}
$$

$\mathrm{Y}_{\mathrm{it}} \& \mathrm{X}_{\mathrm{k}}$ shows the independent and dependent variables, i \&t are subscripts.

$\beta_{\mathrm{k}}$ shows the coefficient, $\varepsilon_{\mathrm{it}}$ is the error term.

To check validity, F-test applied,

$\mathrm{H}_{\mathrm{o}}=\mathrm{O}$

$\mathrm{H}_{1} \neq \mathrm{O}$

When the critical $\mathrm{F}$ value is less than the value of the statistical $\mathrm{F}$, the null hypothesis is rejected.

The random effect approach is the next method of assessing the panel data. The deviation is across randomlyto each section.

$$
\beta_{\mathrm{o}}=\beta+\mathbf{v}_{\mathrm{i}}
$$

Where $\mathrm{v}_{\mathrm{i}}=\mathrm{o}$, Means the standard random variable.

Random effect methodequations as follows:

$$
\begin{gathered}
Y_{i t}=\left(\beta+v_{i)}+\beta_{1} X_{1 i t}+\beta_{2} X_{2 i t}+\ldots \ldots+\beta_{k} X_{k i t}+\varepsilon_{i t}\right. \\
Y_{i t}=\beta+\beta_{1} X_{1 i t}+\beta_{2} X_{2 i t}+\ldots \ldots+\beta_{k} X_{k i t}+\left(v_{i}+\varepsilon_{i t}\right)
\end{gathered}
$$

If the panel dataset contains current cross-sectional data, then the form of fixed effect is more suitable. It is easier than the random effect solution to the cross-sectional results representing several survey studies.

Hausman introduced this test in 1976 under the no correlation assumption. For the decision between the random and fixed effect process, the Hausman test is recognized.

\subsection{Model Specification}

To check the impact of governance, human capital, and FDI on Trade, we have specified the same model for lower-income, lower-middle-income, and upper-middle-income. A fixed and random effect model estimates this model. This model has been specified as follows:

The econometric equation of Trade is specified as follows:

$\mathrm{TRADE}_{i t}=\beta_{o}+\beta_{1} W G I_{i t}+\beta_{2} H C_{i t}+\beta_{3} F D I$ it $+\beta_{4} G D P G_{i t}+\beta_{5} M 2_{i t}+\beta_{6} E R_{i t}+\beta_{7} R E M_{i t}+\beta_{8} T A X_{i t}+\varepsilon_{i t}$ 
Where

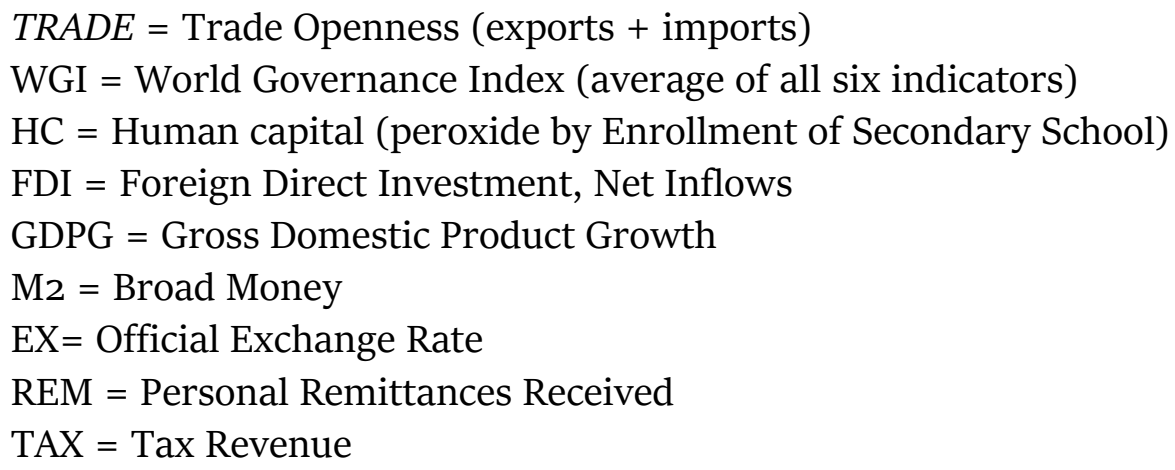

We have specified the same models for lower-income, lower-middle-income, and upper-middleincome countries. If there is no correlation in these models, these models would be estimated by the Hausman test.

\section{Results and Discussion}

\subsection{Descriptive Statistics and Correlation Matrix}

The descriptive statistics and correlation matrix are shown in the following Table 4.1, 4.2, and 4.3. Table 4.1 shows that the average values of all variables of model trade, world governance index, Human capital, foreign direct investment, gross domestic product growth, broad money, exchange rate, remittances, and tax are 20.71, 1.74, 13.78, 25.82, 3.83, 19.04, 403.97, 1.25, 12.21 respectively. While the maximum values of trade, world governance index, Human capital, foreign direct investment, gross domestic product growth, broad money, exchange rate, remittances, and tax are 137.67, 4.26, 41.54, 57.02, 13.57, 646.64, 3334.75, 47.20 and 19.15 respectively and minimum values of trade, world governance index, Human capital, foreign direct investment, gross domestic product growth, broad money, exchange rate, remittances, and tax are -31.33, -1.19, -0.67, -4.14, -3.98, -1.58, -1.38, -1.33, 3.28 respectively. The following table 4.1 also displays the correlation matrix of key variables which is used in our model of lower-income countries. 
Review of Economics and Development Studies, Vol. 7 (3) 2021, 325 - 341

Table 4.1: Descriptive Statistics and Correlation Matrix of Key Variables for Low Income Countries

\begin{tabular}{|c|c|c|c|c|c|c|c|c|c|}
\hline & TRADE & WGI & HC & FDI & GDPG & M2 & ER & REM & TAX \\
\hline Mean & 20.71 & 1.74 & 13.78 & 25.82 & 3.83 & 19.04 & 403.97 & 1.25 & 12.21 \\
\hline Median & 4.04 & 0.00 & 15.89 & 34.21 & 3.09 & -0.52 & -0.17 & -0.69 & 11.92 \\
\hline Maximum & 137.67 & 4.26 & 41.54 & 57.02 & $13 \cdot 37$ & 646.64 & 3334.75 & 47.20 & 19.15 \\
\hline Minimum & -31.33 & -1.19 & -0.67 & -4.14 & -3.98 & -1.58 & -1.38 & -1.33 & 3.28 \\
\hline Std. Dev. & 30.08 & 6.25 & 8.57 & 19.60 & 2.34 & 84.82 & 824.56 & 6.66 & 3.26 \\
\hline Skewness & 1.34 & $4 \cdot 52$ & 0.22 & -0.26 & 1.64 & 6.81 & 2.18 & 6.04 & -0.28 \\
\hline Kurtosis & 4.86 & 24.88 & 2.69 & 1.59 & 8.51 & 48.56 & 6.60 & 40.77 & 3.00 \\
\hline $\begin{array}{l}\text { Jarque- } \\
\text { Bera }\end{array}$ & 46.30 & 2.40 & 1.25 & 9.73 & 178.29 & 9800.46 & 138.32 & 6813.00 & 1.34 \\
\hline Probability & 0.00 & 0.00 & 0.54 & 0.01 & 0.00 & 0.00 & 0.00 & 0.00 & 0.51 \\
\hline Obser. & 378 & 378 & 378 & 378 & 378 & 378 & 378 & 378 & 378 \\
\hline TRADE & 1 & & & & & & & & \\
\hline WGI & -0.18 & 1 & & & & & & & \\
\hline HC & -0.59 & 0.15 & 1 & & & & & & \\
\hline FDI & -0.83 & 0.15 & 0.69 & 1 & & & & & \\
\hline GDPG & 0.50 & -0.10 & -0.42 & -0.44 & 1 & & & & \\
\hline M2 & 0.12 & -0.06 & -0.34 & -0.20 & 0.61 & 1 & & & \\
\hline ER & 0.62 & -0.14 & -0.56 & -0.64 & 0.00 & 0.03 & 1 & & \\
\hline REM & 0.30 & -0.08 & -0.36 & -0.30 & 0.68 & 0.97 & 0.11 & 1 & \\
\hline TAX & -0.24 & 0.34 & 0.38 & 0.36 & -0.19 & -0.39 & -0.35 & -0.43 & 1 \\
\hline
\end{tabular}

The following table 4.2 shows that the average values of all Variables for lower-middle-income countries trade, world governance index, Human capital, foreign direct investment, gross domestic product growth, broad money, exchange rate, remittances, and tax are 83.59, -0.35, 28.50, 25.82, 5.01, $56.06,501.07,8.35,14.82$ respectively. While the maximum values of trade, world governance index, Human capital, foreign direct investment, gross domestic product growth, broad money, exchange rate, remittances, and tax are 156.86, 0.75, 91.67, 57.02, 18.36, 119.35, 8069.61, 34.50 and 28.71 respectively. Minimum values of trade, world governance index, Human capital, foreign direct investment, gross domestic product growth, broad money, exchange rate, remittances, and tax are 22.38, -1.27, 91.67, $4.14,-14.76,12.66,0.91,0.04$ and 4.52 respectively. The following table 4.2 also displays the correlation matrix of key variables which is used in our model of lower-middle-income countries. 
Review of Economics and Development Studies, Vol. 7 (3) 2021, 325 - 341

Table 4.2: Descriptive Statistics and Correlation Matrix for Lower-Middle Income Countries

\begin{tabular}{|c|c|c|c|c|c|c|c|c|c|}
\hline & TRADE & WGI & HC & FDI & GDPG & M2 & ER & REM & TAX \\
\hline Mean & 83.59 & -0.35 & 28.50 & 25.82 & 5.01 & 56.06 & 501.07 & 8.35 & 14.82 \\
\hline Median & 85.49 & -0.30 & 27.71 & 34.21 & 4.83 & $53 \cdot 34$ & $45 \cdot 31$ & $5 \cdot 76$ & 14.77 \\
\hline Maximum & 156.86 & 0.75 & 91.67 & 57.02 & 18.36 & $119 \cdot 35$ & 8069.61 & $34 \cdot 50$ & 28.71 \\
\hline Minimum & 22.38 & -1.27 & 6.79 & -4.14 & -14.76 & 12.66 & 0.91 & 0.04 & 4.52 \\
\hline Std. Dev. & 30.90 & 0.41 & 19.48 & 19.60 & $3 \cdot 50$ & 24.80 & 1160.63 & $7 \cdot 70$ & 4.27 \\
\hline Skewness & 0.07 & -0.11 & $3 \cdot 30$ & -0.26 & -0.48 & 0.61 & 3.14 & 1.37 & 0.20 \\
\hline Kurtosis & 2.12 & 2.65 & $4 \cdot 45$ & 1.59 & 8.54 & 2.94 & 13.89 & $4 \cdot 36$ & 2.77 \\
\hline $\begin{array}{l}\text { Jarque- } \\
\text { Bera }\end{array}$ & 7.85 & 1.71 & 88.29 & 9.73 & 313.81 & 15.02 & 1568.77 & 92.79 & 2.06 \\
\hline Probability & 0.02 & 0.43 & 0.00 & 0.01 & 0.00 & 0.00 & 0.00 & 0.00 & 0.36 \\
\hline Obser. & 630 & 630 & 630 & 630 & 630 & 630 & 630 & 630 & 630 \\
\hline TRADE & 1 & & & & & & & & \\
\hline WGI & -0.03 & 1 & & & & & & & \\
\hline HC & 0.24 & 0.07 & 1 & & & & & & \\
\hline FDI & -0.14 & -0.56 & -0.64 & 1 & & & & & \\
\hline GDPG & 0.05 & 0.00 & -0.20 & 0.00 & 1 & & & & \\
\hline M2 & -0.14 & 0.41 & 0.06 & 0.03 & -0.13 & 1 & & & \\
\hline ER & 0.23 & -0.28 & -0.15 & 0.97 & 0.22 & -0.32 & 1 & & \\
\hline REM & 0.19 & 0.15 & 0.19 & -0.39 & -0.20 & -0.01 & -0.18 & 1 & \\
\hline TAX & 0.27 & 0.38 & 0.33 & -0.21 & -0.18 & 0.42 & -0.21 & 0.29 & 1 \\
\hline
\end{tabular}

The following table 4.3 shows that the average values of all variables for upper-middle-income countries trade, world governance index, Human capital, foreign direct investment, gross domestic product growth, broad money, exchange rate, remittances, and tax are 82.52, -0.10, 43.18, 4.53, 6.89, $66.94,278.16,4.18,16.73$ respectively. While the maximum values of trade, world governance index, Human capital, foreign direct investment, gross domestic product growth, broad money, exchange rate, remittances, and tax are 157.97, 0.67, 93.54, 31.25, 22.56, 207.67, 6177.94, 21.97 and 27.37 respectively. The minimum value of trade, world governance index, Human capital, foreign direct investment, gross domestic product growth, broad money, exchange rate, remittances, and tax are 22.11, -0.96, 9.19, $4.89,-2.58,14.61,0.18$, 0.09 and 7.84 respectively. The following table 4.3 also represents the correlation matrix of variables, which is used in our model of upper-middle-income countries. 
Review of Economics and Development Studies, Vol. 7 (3) 2021, 325 - 341

Table 4.3: Descriptive Statistics and Correlation Matrix of Key Variables for Upper- Middle Income Countries

\begin{tabular}{|c|c|c|c|c|c|c|c|c|c|}
\hline & TRADE & WGI & HC & FDI & GDPG & M2 & ER & REM & TAX \\
\hline Mean & 82.52 & -0.10 & 43.18 & 4.53 & 6.89 & 66.94 & 278.16 & 4.18 & 16.73 \\
\hline Median & 76.51 & -0.13 & 41.83 & $3 \cdot 51$ & $5 \cdot 73$ & 51.20 & 8.21 & 1.57 & 15.67 \\
\hline Maximum & 157.97 & 0.67 & 93.54 & 31.25 & 22.56 & 207.67 & 6177.94 & 21.97 & $27 \cdot 37$ \\
\hline Minimum & 22.11 & -0.96 & 9.19 & -4.89 & -2.58 & 14.61 & 0.18 & 0.09 & 7.84 \\
\hline Std. Dev. & 34.88 & 0.30 & 19.87 & 4.05 & $4 \cdot 48$ & 40.06 & 895.96 & 5.41 & 5.07 \\
\hline Skewness & 0.16 & -0.06 & 0.52 & 2.76 & 2.78 & 1.42 & 4.29 & 1.47 & 0.39 \\
\hline Kurtosis & 1.86 & 3.08 & 2.48 & 14.81 & 2.90 & $4 \cdot 72$ & 22.26 & 3.99 & 2.17 \\
\hline $\begin{array}{l}\text { Jarque- } \\
\text { Bera }\end{array}$ & 12.82 & 0.21 & 12.61 & 1564.71 & 1245.90 & 101.81 & 4093.44 & 88.85 & 11.88 \\
\hline Probability & 0.00 & 0.90 & 0.00 & 0.00 & 0.00 & 0.00 & 0.00 & 0.00 & 0.00 \\
\hline Obser. & 432 & 432 & 432 & 432 & 432 & 432 & 432 & 432 & 432 \\
\hline TRADE & 1 & & & & & & & & \\
\hline WGI & 0.00 & 1 & & & & & & & \\
\hline HC1 & 0.09 & -0.15 & 1 & & & & & & \\
\hline FDI & 0.28 & 0.25 & -0.03 & 1 & & & & & \\
\hline GDPG & 0.19 & 0.15 & 0.19 & -0.21 & 1 & & & & \\
\hline M2 & 0.08 & 0.16 & -0.17 & 0.12 & -0.18 & 1 & & & \\
\hline ER & -0.20 & -0.08 & -0.03 & -0.13 & -0.56 & -0.22 & 1 & & \\
\hline REM & 0.27 & 0.11 & -0.27 & 0.36 & 0.00 & 0.13 & -0.13 & 1 & \\
\hline TAX & 0.47 & 0.27 & -0.25 & 0.32 & 0.41 & -0.13 & -0.30 & 0.35 & 1 \\
\hline
\end{tabular}

\subsection{Unit Root Test}

Table 4.4 shows unit-roots results of all variables by applying LLC, IPS, and Fisher-ADF Chisquare tests. Results show that all variables TRADE, WGI, HC, FDI, GDPD, M2, ER, REM, and TAX are stationary at level. So we are applied random and fixed effect model econometric techniques apply for determining the long-run relationship results. 
Table 4.4: Results of unit root

\begin{tabular}{|c|c|c|c|c|c|c|c|c|c|c|c|c|c|}
\hline \multirow{4}{*}{$\begin{array}{l}\text { Test for } \\
\text { Unit } \\
\text { Root In }\end{array}$} & \multicolumn{13}{|l|}{ Level } \\
\hline & \multicolumn{4}{|c|}{ Low Income Countries } & \multicolumn{4}{|c|}{ Low Middle Income Countries } & \multicolumn{4}{|c|}{ Upper Middle Income Countries } & \multirow{3}{*}{ Result } \\
\hline & \multicolumn{2}{|l|}{ IPS } & \multicolumn{2}{|l|}{ LLC } & \multicolumn{2}{|l|}{ IPS } & \multicolumn{2}{|l|}{ LLC } & \multicolumn{2}{|l|}{ IPS } & \multicolumn{2}{|l|}{ LLC } & \\
\hline & Intercept & \begin{tabular}{|l} 
Intercept \\
+ \\
Trend \\
\end{tabular} & Intercept & $\begin{array}{l}\text { Intercept } \\
+ \\
\text { Trend } \\
\end{array}$ & Intercept & $\begin{array}{l}\text { Intercept } \\
+ \\
\text { Trend }\end{array}$ & Intercept & $\begin{array}{l}\text { Intercept } \\
+ \\
\text { Trend }\end{array}$ & Intercept & $\begin{array}{l}\text { Intercept } \\
+ \\
\text { Trend }\end{array}$ & Intercept & $\begin{array}{l}\text { Intercept } \\
+ \\
\text { Trend } \\
\end{array}$ & \\
\hline Trade & $\begin{array}{r}-2.19250 \\
(0.0142) \\
\end{array}$ & $\begin{array}{r}-2.66382 \\
(0.0039) \\
\end{array}$ & $\begin{array}{l}2.93074 \\
(0.9983) \\
\end{array}$ & $\begin{array}{c}-5.10504 \\
0.0000) \\
\end{array}$ & $\begin{array}{c}-1.11163 \\
(0.1331) \\
\end{array}$ & $\begin{array}{c}1.45557 \\
(0.9272) \\
\end{array}$ & $\begin{array}{l}-3.24044 \\
(0.0006)\end{array}$ & $\begin{array}{l}-3.12481 \\
(0.0009) \\
\end{array}$ & $\begin{array}{l}-1.44761 \\
(0.0739) \\
\end{array}$ & $\begin{array}{c}-1.24978 \\
(0.1057) \\
\end{array}$ & $\begin{array}{l}-2.40934 \\
(0.0080) \\
\end{array}$ & $\begin{array}{l}-4.45731 \\
(0.0000) \\
\end{array}$ & $\mathrm{I}(\mathrm{o})$ \\
\hline WGI & $\begin{array}{c}1.14487 \\
(0.8739) \\
\end{array}$ & $\begin{array}{l}0.07921 \\
(0.5316) \\
\end{array}$ & $\begin{array}{c}0.57409 \\
(0.7170)\end{array}$ & $\begin{array}{l}-2.93671 \\
(0.0017)\end{array}$ & $\begin{array}{c}2.25332 \\
(0.9879) \\
\end{array}$ & $\begin{array}{r}-1.84350 \\
(0.0326) \\
\end{array}$ & $\begin{array}{c}0.17324 \\
(0.5688) \\
\end{array}$ & $\begin{array}{l}-7.33930 \\
(0.0000) \\
\end{array}$ & $\begin{array}{c}1.17656 \\
(0.8803) \\
\end{array}$ & $\begin{array}{c}1.49972 \\
(0.9332) \\
\end{array}$ & $\begin{array}{l}-0.63460 \\
(0.2628) \\
\end{array}$ & $\begin{array}{l}0.60926 \\
(0.7288) \\
\end{array}$ & $\mathrm{I}(\mathrm{O})$ \\
\hline SSE & $\begin{array}{l}-5.00315 \\
(0.0000)\end{array}$ & $\begin{array}{l}0.53690 \\
(0.7403)\end{array}$ & $\begin{array}{c}12.5746 \\
\text { (o.00o0) }\end{array}$ & $\begin{array}{l}-5.24764 \\
(0.0000)\end{array}$ & $\begin{array}{c}3.56375 \\
(0.9998) \\
\end{array}$ & $\begin{array}{c}4.31608 \\
(1.0000)\end{array}$ & $\begin{array}{l}-1.32780 \\
(0.0921) \\
\end{array}$ & $\begin{array}{l}0.55493 \\
(0.7105)\end{array}$ & $\begin{array}{l}1.66406 \\
\text { (o.9519) }\end{array}$ & $\begin{array}{c}2.11826 \\
(0.9829)\end{array}$ & $\begin{array}{l}-10.1370 \\
(0.0000)\end{array}$ & $\begin{array}{l}0.63942 \\
(0.7387)\end{array}$ & $\mathrm{I}(\mathrm{O})$ \\
\hline FDI & $\begin{array}{l}-3.18448 \\
(0.0007) \\
\end{array}$ & $\begin{array}{c}-0.70255 \\
(0.24212) \\
\end{array}$ & $\begin{array}{l}-4.57326 \\
(0.0000) \\
\end{array}$ & $\begin{array}{l}-4.43109 \\
(0.0000)\end{array}$ & $\begin{array}{l}-5.17992 \\
(0.0356) \\
\end{array}$ & $\begin{array}{c}-0.55084 \\
(0.0856) \\
\end{array}$ & $\begin{array}{l}-4.57326 \\
(0.0019) \\
\end{array}$ & $\begin{array}{l}-9.22548 \\
(0.0047) \\
\end{array}$ & $\begin{array}{l}-17.0335 \\
(0.0000) \\
\end{array}$ & $\begin{array}{l}-12.2799 \\
(0.0000)\end{array}$ & $\begin{array}{l}-22.0726 \\
(0.0000)\end{array}$ & $\begin{array}{l}-19.2988 \\
(0.0000) \\
\end{array}$ & $\mathrm{I}(\mathrm{o})$ \\
\hline GDPG & $\begin{array}{l}-7.97685 \\
(0.0000) \\
\end{array}$ & \begin{tabular}{|l|}
-5.20975 \\
$(0.0000)$ \\
\end{tabular} & $\begin{array}{l}-6.76100 \\
(0.0000) \\
\end{array}$ & $\begin{array}{l}-6.31584 \\
(0.0000) \\
\end{array}$ & $\begin{array}{r}-9.08167 \\
(0.0000) \\
\end{array}$ & $\begin{array}{l}-7.87575 \\
(0.0000) \\
\end{array}$ & $\begin{array}{l}-10.4064 \\
(0.0000) \\
\end{array}$ & $\begin{array}{c}-11.5331 \\
(0.0000) \\
\end{array}$ & $\begin{array}{r}-7.58499 \\
(0.0000) \\
\end{array}$ & $\begin{array}{l}-9.45831 \\
(0.0000) \\
\end{array}$ & $\begin{array}{l}-8.73253 \\
(0.0000) \\
\end{array}$ & $\begin{array}{l}-12.9637 \\
(0.0000) \\
\end{array}$ & $\mathrm{I}(\mathrm{o})$ \\
\hline M2 & $\begin{array}{c}2.64793 \\
(0.0960) \\
\end{array}$ & $\begin{array}{c}1.07529 \\
(0.0089) \\
\end{array}$ & $\begin{array}{l}-0.23811 \\
(0.0259) \\
\end{array}$ & $\begin{array}{r}-1.24433 \\
(0.0167) \\
\end{array}$ & $\begin{array}{r}2.23601 \\
(0.0273) \\
\end{array}$ & $\begin{array}{c}2.31833 \\
(0.0898) \\
\end{array}$ & $\begin{array}{l}-0.85303 \\
(0.0968) \\
\end{array}$ & $\begin{array}{l}-1.02174 \\
(0.0035) \\
\end{array}$ & $\begin{array}{c}1.46767 \\
(0.0989) \\
\end{array}$ & $\begin{array}{r}-0.62714 \\
(0.0653) \\
\end{array}$ & $\begin{array}{r}-2.14949 \\
(0.0158) \\
\end{array}$ & $\begin{array}{r}-4.09302 \\
(0.0000) \\
\end{array}$ & $\mathrm{I}(\mathrm{o})$ \\
\hline ER & $\begin{array}{r}1.78903 \\
(0.9632) \\
\end{array}$ & $\begin{array}{c}0.92591 \\
(0.8228) \\
\end{array}$ & $\begin{array}{l}0.80805 \\
(0.7905) \\
\end{array}$ & $\begin{array}{l}-2.74296 \\
(0.0030)\end{array}$ & $\begin{array}{l}32.0880 \\
(1.0000) \\
\end{array}$ & $\begin{array}{c}20.8102 \\
(1.0000) \\
\end{array}$ & $\begin{array}{l}5 \cdot 37742 \\
(1.0000) \\
\end{array}$ & $\begin{array}{c}1.10895 \\
(0.8663) \\
\end{array}$ & $\begin{array}{r}2.01257 \\
(0.9779) \\
\end{array}$ & $\begin{array}{l}0.97835 \\
(0.8360 \\
\end{array}$ & $\begin{array}{l}-0.37549 \\
(0.3536) \\
\end{array}$ & $\begin{array}{l}-3.50708 \\
(0.0002) \\
\end{array}$ & $\mathrm{I}(\mathrm{o})$ \\
\hline REM & $\begin{array}{l}-0.72636 \\
(0.2338) \\
\end{array}$ & $\begin{array}{l}-1.01964 \\
(0.1539) \\
\end{array}$ & $\begin{array}{l}-2.57749 \\
(0.0050) \\
\end{array}$ & $\begin{array}{l}-4.35707 \\
(0.0000) \\
\end{array}$ & $\begin{array}{c}-0.01663 \\
(0.4934) \\
\end{array}$ & $\begin{array}{l}-0.22835 \\
(0.4097)\end{array}$ & $\begin{array}{l}-2.63421 \\
(0.0042) \\
\end{array}$ & $\begin{array}{l}-3.48757 \\
(0.0002) \\
\end{array}$ & $\begin{array}{c}-1.93768 \\
(0.0263) \\
\end{array}$ & $\begin{array}{l}-0.55123 \\
(0.2907)\end{array}$ & $\begin{array}{l}-3.77537 \\
\text { (0.0001) }\end{array}$ & $\begin{array}{c}-2.69643 \\
0.0035) \\
\end{array}$ & $\mathrm{I}(\mathrm{o})$ \\
\hline TAX & $\begin{array}{c}-0.84266 \\
(0.1997)\end{array}$ & $\begin{array}{l}-0.27325 \\
(0.3923)\end{array}$ & $\begin{array}{l}-3.45917 \\
(0.0003)\end{array}$ & $\begin{array}{l}-4.72484 \\
(0.0000)\end{array}$ & $\begin{array}{l}-7.03290 \\
(0.0000)\end{array}$ & $\begin{array}{c}0.34194 \\
(0.6338)\end{array}$ & $\begin{array}{l}-22.1781 \\
(0.0000)\end{array}$ & $\begin{array}{l}-3.97880 \\
(0.0000)\end{array}$ & $\begin{array}{r}-1.10353 \\
(0.1349)\end{array}$ & $\begin{array}{r}-1.02407 \\
(0.1529)\end{array}$ & $\begin{array}{l}-3.60742 \\
(0.0002)\end{array}$ & $\begin{array}{l}-5.32539 \\
(0.0000)\end{array}$ & $\mathrm{I}(\mathrm{o})$ \\
\hline
\end{tabular}


Review of Economics and Development Studies, Vol. 7 (3) 2021, 325 - 341

Hausman test determines whether the fixed-effect method is used or the random effect method is used. The null hypothesis is that the random effect method is efficient and consistent. If the value of the Hausman statistic is high then our null hypothesis is rejected random effect model is exists. So, it is more appropriate to use estimators of fixed effects. If the Hausman statistic value is low then we use the random effect model. The results of this test presented in the following table. The following table shows that lower-income, lower-middle-income, and upper-middle-income countries result from random effect models, which shows the p-values of these countries' models less than 10 percent. So the fixed effect model consists of the estimation of long-run relationships.

Table 4.5: Hausman Test for Trade Models

\begin{tabular}{|l|l|l|l|}
\hline Test Summary & $\begin{array}{l}\text { Chi-Sq. } \\
\text { Statistic }\end{array}$ & Chi-Sq. d.f. & Prob. \\
\hline Correlated Random Effect Test for low income countries & 5.12 & 9 & 0.023 \\
\hline $\begin{array}{l}\text { Correlated Random Effect Test for low middle income } \\
\text { countries }\end{array}$ & 2.56 & 9 & 0.052 \\
\hline $\begin{array}{l}\text { Correlated Random Effect Test for upper middle income } \\
\text { countries }\end{array}$ & 3.8 & 9 & 0.006 \\
\hline
\end{tabular}

\subsection{Results of Fixed Effect Models}

In this section, we will discuss the results of fixed effect estimate of trade models for low, Middle and upper-middle-income countries. This result shows the relationship between world governance and trade negative but significant. The negative coefficient of the world governance index shows bad institutional quality decrease overall trade by increasing costs for transactions that a 1percent change in the world governance index will bring changes in the opposite direction in trade by 0.6079 percent. Other variables like human capital, foreign direct investment and money supply affected negatively while GDP growth, exchange rate, remittances and tax are associated positively with trade.

\section{Table 4.6: Fixed Effect Estimates of Trade Model for Low-Income Countries}

\begin{tabular}{|l|l|l|l|l|}
\hline \multicolumn{5}{|c|}{ Dependent Variable: TRADE } \\
\hline Variable & Coefficient & Std. Error & t-Statistic & Prob. \\
\hline C & 17.5606 & 4.3075 & 4.0767 & 0.0001 \\
\hline WGI & -0.6079 & 0.3211 & -1.8932 & 0.0610 \\
\hline HC & -0.4795 & 0.1250 & -3.8346 & 0.0002 \\
\hline FDI & -0.6143 & 0.0606 & -10.1389 & 0.0000 \\
\hline GDPG & 2.3029 & 0.4936 & 4.6653 & 0.0000 \\
\hline M2 & -0.5859 & 0.0364 & -16.0965 & 0.0000 \\
\hline ER & 0.0073 & 0.0013 & 5.7431 & 0.0000 \\
\hline REM & 7.4082 & 0.5033 & 14.7195 & 0.0000 \\
\hline TAX & 1.3395 & 0.2618 & 5.1156 & 0.0000 \\
\hline
\end{tabular}

This result shows the relationship between world governance, fdi and money supply negatively affected trade in case of lower middle income countries. These variables effected trade significantly. Other variables like human capital, GDP growth, exchange rate, remittances and tax are associated positively with trade. 
Review of Economics and Development Studies, Vol. 7 (3) 2021, 325 - 341

Table 4.7: Fixed Effect Estimates of Trade Model for Low-Middle-Income Countries

\begin{tabular}{|l|l|l|l|l|}
\hline \multicolumn{5}{|c|}{ Dependent Variable: TRADE } \\
\hline Variable & Coefficient & Std. Error & t-Statistic & Prob. \\
\hline C & 13.0934 & 5.4069 & 2.4216 & 0.0164 \\
\hline WGI & -25.1537 & 8.1693 & -3.0790 & 0.0024 \\
\hline HC & 0.1964 & 0.1214 & 1.6172 & 0.1075 \\
\hline FDI & -0.4420 & 0.2395 & -1.8458 & 0.0665 \\
\hline GDPG & 1.7030 & 0.5227 & 3.2579 & 0.0013 \\
\hline M2 & -0.1791 & 0.0900 & -1.9897 & 0.0480 \\
\hline ER & 0.0129 & 0.0023 & 5.5453 & 0.0000 \\
\hline REM & 0.7293 & 0.2828 & 2.5790 & 0.0107 \\
\hline TAX & 4.4889 & 0.4715 & 9.5206 & 0.0000 \\
\hline
\end{tabular}

Table 4.8 presented the first relationship between the world governance index and trade for upper-middle-income countries. The empirical results show that governance affected trade negatively. While other variables like human capital, GDP growth, exchange rate, remittances, money supply and tax show positive relation with trade. More specifically, increase in human capital, GDP growth, exchange rate, remittances, money supply and tax will increase trade significantly.

Table 4.8: Fixed Effect Estimates of Model for Upper Middle Income Countries

\begin{tabular}{|l|l|l|l|l|}
\hline \multicolumn{5}{|c|}{ Dependent Variable: TRADE } \\
\hline Variable & Coefficient & Std. Error & t-Statistic & Prob. \\
\hline C & -24.6986 & 11.9765 & -2.0623 & 0.0404 \\
\hline WGI & -15.3608 & 7.0699 & -2.1727 & 0.0309 \\
\hline HC & 0.3970 & 0.1092 & 3.6348 & 0.0003 \\
\hline FDI & 0.7044 & 0.5299 & 1.3292 & 0.1852 \\
\hline GDPG & 0.7261 & 0.2511 & 2.8910 & 0.0042 \\
\hline M2 & 0.2111 & 0.0548 & 3.8558 & 0.0002 \\
\hline ER & 0.0014 & 0.0023 & 0.6121 & 0.5411 \\
\hline REM & 0.7988 & 0.4034 & 1.9801 & 0.0490 \\
\hline TAX & 3.7228 & 0.4707 & 7.9087 & 0.0000 \\
\hline
\end{tabular}

\section{Conclusion and Policy Recommendation}

Our study analyzed the impact of governance, foreign direct investment and human capital on trade liberalization in developing countries (lower income, middle income and upper middle income) for the period of 2000 to 2019 by employing fixed effect. The findings show governance, foreign direct investment and human capital are highly significant with trade liberalization in the case of lowerincome countries. In the case of middle-income countries, empirical findings demonstrate governance and foreign direct investment are highly significant with a negative sign, while human capital has positive on trade liberalization. In the case of upper-middle-income countries, results show human 
Review of Economics and Development Studies, Vol. 7 (3) 2021, 325 - 341

capital and foreign direct investment affect positively, while governance has a negative effect on trade liberalization. On the behalf of results the study recommends the following policy suggestions:

- Developing countries must focus on policies that encourage institutional growth that attract foreign direct investment but, more importantly, are able to target foreign investment in sectors which will lead to higher returns on local investments.

- On the behalf of results it is suggested that in the countries where human capital is high, most of the inflows of foreign direct investment happen. It means that the government can develop human resources to attract more foreign direct investments. The governments of developing countries should also concentrate on education, including training facilities and other quality educational facilities for human skill development.

- There needs to be a good policy and economic climate, investment in vital infrastructure, stability at all levels of the state, governance system should be base on accountability, transparency, reliable and effective resources.

\section{References}

Agrawal, G., \& Khan, M. A. (2011). "Impact of FDI on GDP: A comparative study of China and India". International Journal of Business and Management, 6(10), 71.

Ahmad, M. A., Hashmi, A., Ali, W., \& Faheem, M. (2021). The Influence of Human Resource Management Practices on the SMEs Performance: Mediating Role of Employee Engagement. Review of Education, Administration \& LAW, 4(1), 79-91.

Akujur., and Abovu, C., (2015). Local Government Good Governance and Sustainable Development in Nigeria: A Case of Study of Emohua Local Government Area of Rivers State (2001-2012). Global Journal of Political Sciences and Administration. Vol. 3, No. 1, pp. 32-50, March 2015 .

Anwar, Y., Farooq, F., Ullah, S., \& Faheem, M. (2016). Impact of Financial Globalization on Human Capital: Evidence from Pakistan. Pakistan Journal of Social Sciences (PJSS), 36(2).

Asghar, N., Awan, A. Rehman, H. (2012). Human Capital and Economic Growth in Pakistan: A Co- integration and Causality Analysis. International Journal of Economics and Finance, $\quad 4(4),: 135-147$.

Awan, A G., Firidi, M Z. Ch., H A. (2015). Human Capital Formation and Economic Performance: A Case Study of Pakistan. Journal of Economics and Sustainable Development, 6, (3),: 96-104.

Azam, M., Ahmad, A. (2014).Role of Human Capital and Foreign Direct Investment in Promoting Economic Growth.Evidence from Common Wealth of Independent States.International Journal of Social Economics, 42 :98-111.

Azam, M. (2021). Governance and economic growth: evidence from 14 Latin America and Caribbean countries. Journal of the Knowledge Economy, 1-26.

Chani, M I., Hassan, M. Shahid, M. (2012). Human Capital Formation and Economic Development in Pakistan: An Empirical Analysis. http: // mpra.ub.uni_muenchen.de 1389257 [ accussed August 18, 2016]. Development, 6, (3),: 96-104.

Chaudhry, I. S., Faheem, M., Hussain, J., \& Ahmad, R. (2021). A Step towards enhancement of Macroeconomic Performance of Pakistan: Do Oil Price, Public Expenditures and Financial Development Matter?. Review of Applied Management and Social Sciences, 4(1), 157-168.

Chowdhury, M. N. M., Uddin, M. J., Uddin, N., \& Uddin, S. (2018). Human capital development and economic growth in Bangladesh. Journal of World Economic Research, 7(2), 52-63.

Dada, J. T., \& Abanikanda, E. O. (2021). The moderating effect of institutions in foreign direct investment led growth hypothesis in Nigeria. Economic Change and Restructuring, 1-27. 
Review of Economics and Development Studies, Vol. 7 (3) 2021, 325 - 341

Emmanuel, O. N. (2014). Foreign direct investment and economic growth: The experience of CEMAC countries. Journal of Finance \& Economics, 2(1), 01-14.

Fang, Z., Chang, Y. (2016). Energy, Human Capital and Economic Growth in Asia Fang, Z., \& Chang, Y. (2016). Energy, human capital and economic growth in Asia Pacific countriesEvidence from a panel cointegration and causality analysis. Energy Economics, 56, 177-184.

Fazekas, M., \& Czibik, Á. (2021). Measuring regional quality of government: the public spending quality index based on government contracting data. Regional Studies, 1-14.

Fraj, S. H., Hamdaoui, M., \&Maktouf, S. (2018). Governance and economic growth: The role of the exchange rate regime. International economics, 156, 326-364.

Gerhards, J., Hans, S. (2013). International Human Capital, Education and Social Growth in Pakistan. Pakistan Journal of Social Science, 32 (1),: 229-240.

Iqbal, A., and Mehar, A., (2015). Governance Issues In Pakistan and Their Impact on income Inequality. IBT Journal of Business Studies (Formerly Journal of Management \& Social Sciences). Vol. 11, No. 2, (Fal12015) 213-228.

Jun, S. (2015). “The Nexus between FDI and Growth in the SAARC Member Countries”.East Asian Economic Integration (JEAI),19(1), 39-70.

Khosroabadi, M., (2016). The Effect of The Quality of Governance on Income Distribution: With an Emphasis on Iran and Selected Countries Neighbouring Turkey and Pakistan. International Business Management. 10(10) 2023-2026. 2016.

Lahouij, H., (2016). Does Governance Matter to Economic Growth? Evidence from MENA Countries.

Li, F., Liang, T., \& Zhou, X. (2021). How Does Intellectual Property Protection in the Host Country Affect Outward Foreign Direct Investment?. Research in International Business and Finance, 101476.

Maitra, B., \& Chakraborty, M. (2021). International trade, human capital and economic growth in Sri Lanka. International Journal of Economic Policy Studies, 1-22.

Matousek, R., \& Tzeremes, N. G. (2021). The asymmetric impact of human capital on economic growth. Empirical Economics, 60(3), 1309-1334.

Mawila, E., \& Nyambe, J. M. (2015).Investigating the impact of FDI on economic growth in Zambia: 1980-2012.

Muringani, J., Fitjar, R. D., \& Rodríguez-Pose, A. (2021). Social capital and economic growth in the regions of Europe. Environment and Planning A: Economy and Space, 0308518X211000059.

Omotayo, O., A. (2015). The Impact of Human Capital Development on Economic Growth in Nigeria.International Journal of Recent Research in Commerce Economics and Management, 2 (2),: 151-164.

Osei, M. J., \& Kim, J. (2020). Foreign direct investment and economic growth: Is more financial development better?. Economic Modelling, 93, 154-161.

Owusu-Nantwi, V., \& Erickson, C. (2019).Foreign direct investment and economic growth in South America.Journal of Economic Studies.

Özdoğan Özbal, E. (2021). Dynamic effects of higher education expenditures on human capital and economic growth: an evaluation of OECD countries. Policy Reviews in Higher Education, 123.

Samar, B., Waqas, M. (2014).Human Capital Formation and Economic Growth in Pakistan. World Applied Science Journal, 32 (4),: 635-641.

Shuaib, I. M., Ndidi, D. E., Isaac, I., \& Pogoson, O. O. (2015)."The Impact of Foreign Direct Investment (FDI) on the Growth of the Nigerian Economy".International Journal, 38.

Samantha, N. P. G., \&Haiyun, L. (2017). The impact of FDI on the economic growth of Sri Lanka: 
an ARDL approach to Co-integration. International Journal of Innovation and Economic Development, 3(5), 70-82.

Sokang, K. (2018). The impact of foreign direct investment on the economic growth in Cambodia: Empirical evidence. International Journal of Innovation and Economic Development, 4(5), 31-38.

Siddique, H. M. A., Ansar, R., Naeem, M. M., \& Yaqoob, S. (2017). Impact of FDI on economic growth: Evidence from Pakistan. Bulletin of Business and Economics, 6(3), 111-116.

Xu, X., Abbas, H. S. M., Sun, C., Gillani, S., Ullah, A., \& Raza, M. A. A. (2021). Impact of globalization and governance determinants on economic growth: An empirical analysis of Asian economies. Growth and Change.

Zakarias, S. M. (2016). "The Impact of Foreign Direct Investment (FDI) on Economic Growth in Eastern Africa: Evidence from Panel Data Analysis". Applied Economics and Finance, 3(1), 145-16o.

Zeb, N., Qiang, F., \& Rauf, S. (2013)."Role of Foreign Direct Investment in Economic Growth of Pakistan”.International Journal of Economics and Finance, 6(1), 32. 